Journal of Telenursing (JOTING)

Volume 3, Nomor 1, Juni 2021

e-ISSN: 2684-8988

p-ISSN: 2684-8996

DOI: https://doi.org/10.31539/joting.v3i1.2093

IDMEKpe

\title{
PENERAPAN POSTER TERHADAP KEPEDULIAN PERAWAT DALAM MENGURANGI NYERI PADA PROSEDUR PENUSUKAN TUMIT DAN PEMBULUH DARAH VENA PADA NEONATUS
}

\author{
Eleni Kenanga Purbasary \\ Sekolah Tinggi Ilmu Kesehatan Indramayu \\ eleni.kenanga@gmail.com
}

\begin{abstract}
ABSTRAK
Penelitian ini bertujuan untuk mengetahui pengaruh penerapan poster terhadap kepedulian mengurangi nyeri pada prosedur penusukan tumit dan pembuluh darah vena. Desain penelitian yang digunakan dalam penelitian ini adalah quasi-eksperiment onegrup pre dan post-test. Hasil penelitian menunjukkan adanya peningkatan kepedulian perawat sebanyak 26 orang $(49,1 \%), 95 \%$ CI pada rentang 0,35-0,63 dengan $P$-value sebesar 0,001. Simpulan, terdapat peningkatan kepedulian perawat dalam upaya mengurangi nyeri pada neonatus setelah penerapan poster.
\end{abstract}

Kata Kunci: Kepedulian Perawat, Nyeri, Penusukan Tumit, Poster

\section{ABSTRACT}

This study aims to determine the effect of posters on awareness to reduce pain in the heel and vein pricking procedure. The research design used in this study was a onegroup quasi-experiment pre and post-test. The results showed an increase in nurse care by 26 people (49.1\%), 95\% CI in the range of 0.35-0.63 with a P-value of 0.001. In conclusion, there is an increase in nurses' care to reduce neonates' pain after the poster's application.

Keywords: Nurse Care, Pain, Heel Stabbing, Poster

\section{PENDAHULUAN}

Neonatus seringkali membutuhkan pengobatan dan perawatan intensif untuk mempertahankan kelangsungan hidupnya dan selama dirawat di rumah sakit sering mendapatkan tindakan invasif yang menyebabkan nyeri (Williams \& Lascelles, 2020). Nyeri sebagai pengalaman emosional dan tidak menyenangkan pada bayi yang dihadapkan pada cedera atau masalah yang terjadi di jaringan tubuh. Pada bayi pengalaman menyakitkan akibat rangsangan nyeri dapat diamati dari tangisan dan ekspresi wajah (Hertel et al., 2019). Pengalaman menyakitkan pada bayi dapat berdampak negatif pada otak bayi. Nyeri prosedural merupakan salah satu masalah yang sering dialami oleh bayi (Ranjbar et al., 2020).

Nyeri pada neonatus jika tidak ditangani dengan baik akan berefek jangka panjang, yaitu dapat berupa gangguan neurobehavioral, gangguan belajar, keterlambatan perkembangan, gangguan motorik, ketidakmampuan menghadapi situasi baru dan peningkatan respon stres hormonal (Walker et al., 2019). Neonatus mendapatkan pengalaman nyeri yang dirasakan oleh tubuhnya tidak hanya dari faktor 
fisiologis saja akan tetapi didapatkan juga dari prosedur tindakan medis dan tindakan keperawatan.

Berdasarkan penelitian Constanza et al., (2021) sebanyak 21.291 tindakan prosedur telah dilakukan dan didokumentasikan di ruang bayi. Sebanyak 18.131 $(85,2 \%)$ tindakan merupakan prosedur yang menyebabkan stress bagi bayi dan 3.160 $(14,8 \%)$ merupakan sejumlah prosedur invasif yang menyakitkan dan merusak kulit. Ada beberapa metode non farmakologi untuk menurunkan nyeri pada pengambilan darah. Metode non farmakologi ini antara lain non nutritive sucking (NNS/Kempeng), breastfeeding, skin to skin contact, pembedongan, facilitated tucking (memposisikan fleksi fisiologis).

Menurut penelitian Pramesti et al., (2018) ada pengaruh pemberian non nutritive sucking (pacifier) terhadap respon nyeri neonatus yang dilakukan pemasangan infus. Nyeri saat pemasangan infus dialihkan dengan efek analgetik non nutritive sucking yang mengaktifkan jalur opioid oleh stimulasi mekanisme orotactile dan mechanoreceptor sehingga nyeri teralihkan. Non nutritive sucking (pacifier) dapat menjadi salah satu alternatif nonfarmakologi dalam meminimalisasi nyeri pada neonatus.

Menurut Peng et al., (2021) mengatakan non nutritive sucking dan fucilitated tucking membantu pemulihan bayi dari rasa nyeri, nyeri yang dialami akan berkurang. Nyeri yang dialami oleh bayi akan mempengaruhi pertumbuhan dan perkembangan serta proses penyembuhan penyakit. Hal ini sejalan dengan hasil penelitian yang dilakukan oleh beberapa peneliti tentang manajemen non farmakologi. Penelitian yang dilakukan Mohammed (2018) mengenai teknik non farmakologi facilitated tucking dan pembedongan pada saat pemasangan OGT menunjukkan hasil bahwa skor nyeri pada kelompok facilitated tucking dan pembedongan tidak menyebabkan rasa sakit dibandingkan dengan kelompok kontrol yang tidak dilakukan fucilitate tucking dan pembedongan dengan (p-value: 0,00$)$.

Penelitian Dur et al., (2020) membuktikan bahwa terapi sentuhan dapat memberikan kenyamanan dan menurunkan nyeri pada neonatus yang dilakukan pengambilan darah tumit ditandai dengan penurunan skor nyeri dari 3 menjadi 0 , sedangkan kelompok kontrol sebaliknya, yaitu: terjadi penambahan skor dari 3 menjadi 4. Hasil penelitian Oktaviani, Rustina, \& Efendi, (2018) dari empat puluh bayi pada sampel penelitian dibagi menjadi dua kelompok; kelompok intervensi $(n=20)$ dengan facilitated tucking dan kelompok kontrol $(\mathrm{n}=20)$ tanpa facilitated tucking, didapatkan hasil berupa perbedaan lama menangis pada kelompok intervensi menjadi lebih singkat. Facilitated tucking efektif mengurangi nyeri dan lama menangis selama pengambilan darah dan dapat diterapkan sebagai bagian dari asuhan perkembangan untuk mendukung program pengendalian nyeri pada neonatus.

Murtiningsih \& Nurbayanti (2021) mengatakan bahwa prosedur non farmakologi pemberian ASI dan pijat bayi mengurangi skala nyeri neonatus selama prosedur pengambilan sampel darah intravenous dan bayi yang dilakukan tindakan non farmakologi memiliki skor nyeri terendah pada kelompok intervensi. Hal ini menandakan bahwa tindakan non farmarmakologi efektif mengurangi nyeri pada bayi yang dilakukan tindakan invasif.

Atraumatic care adalah perawatan yang tidak menimbulkan adanya trauma pada anak dan keluarga dan difokuskan dalam pencegahan terhadap trauma yang merupakan bagian dalam keperawatan anak dan autramatic care dapat mengurangi stress fisik maupun psikologis pada anak yang dirawat (Delfatmawati \& Mariyana, 2020). Teknik manajemen nyeri merupakan bagian dari atraumatic care. Metode farmakologi dan non 
farmakologi merupakan teknik manajemen nyeri. Dalam prosedur rutin di ruang perawatan bayi, metode farmakologi untuk menurunkan nyeri pada neonatus digunakan hanya jika pengkajian skor nyeri bayi dalam kategori nyeri berat (Constanza et al., 2021).

Berdasarkan hasil observasi yang dilakukan di Ruang Perinatologi didapatkan data bahwa dari 15 perawat yang melakukan penusukan tumit dan pembuluh darah vena, 12 orang perawat belum melakukan manajemen non farmakologi dan 3 orang perawat sudah melakukan manajemen non farmakologi menggunakan dot dan bedong. Dalam hal ini perawat mempunyai peranan penting dalam pelaksanaan manajemen non farmakologi. Pelaksanaan manajemen non farmakologi sangat tergantung pada kepatuhan perawat dikarenakan selama bayi di rawat di rumah sakit dan dilakukan tindakan invasif perawat terlibat langsung dengan bayi dalam melakukan prosedur invasif. Oleh karena itu, dalam upaya peningkatan informasi dan perilaku perawat dalam menerapkan manajemen non farmakologi bagi bayi yang dilakukan tindakan invasif, maka perlu dilakukan penempelan poster di setiap ruang bayi guna meningkatkan pengetahuan perawat dalam menerapkan manajemen non farmakologi.

\section{METODE PENELITIAN}

Desain yang digunakan dalam proyek inovasi ini adalah metode quasi experiment desain one-group pre dan post-test. Merupakan desain eksperimen yang hanya menggunakan satu kelompok subjek serta melakukan pengukuran sebelum diberi perlakuan (pre-test) dan sesudah perlakuan (post-test). Populasi dalam penelitian ini adalah seluruh perawat pelaksana yang bekerja di Ruang Perinatologi RSCM. Untuk menentukan jumlah sasaran dalam proyek inovasi ini, peneliti menggunakan teknik convenience (accidental) sampling.

Perhitungan sampel dalam penelitian ini menggunakan uji hipotesis beda rata-rata berpasangan. Sampel dalam penelitian sebanyak 53 respoden dengan tempat pelaksanaan di Ruang Perinatologi (SCN I, SCN 2, SCN 3, SCN 4 dan NICU) RSCM. Kriteria inklusi: a) perawat tidak sedang cuti pada saat proses penelitian dilakukan; b) perawat bersedia menjadi responden dan menandatangani surat persetujuan menjadi responden; c) perawat yang melakukan prosedur penusukan tumit dan pembuluh darah vena dan kriteria inklusi perawat yang tidak mengikuti keseluruhan penelitian.

Analisis data menggunakan uji non parametrik, yaitu uji Wilcoxon. Penelitian ini sudah mendapatkan persetujuan dari Komite Etik Fakultas Ilmu Keperawatan Universitas Indonesia dengan nomor 70/UN2.F12.D/HKP.02.04/2018 dan pelaksanaannya sudah memenuhi prinsip etik seperti diberikan penjelasan tentang tujuan penelitian dan menandatangani lembar persetujuan yang menandakan penerimaan responden untuk terlibat dalam penelitian, menjaga kerahasiaan responden, menyediakan waktu yang cukup leluasa saat pengambilan data. Penelitian ini juga menerapkan prinsip keadilan dengan memberikan perlakuan yang sama kepada responden selama maupun setelah penelitian berakhir. 


\section{HASIL PENELITIAN}

Karakteristik Responden

Karakteristik perawat meliputi data numerik yaitu usia dan masa kerja. Adapun data kategori yaitu jenis kelamin dan pendidikan.

Tabel. 1

Rerata Usia dan Masa Kerja Responden Perawat

$(n=53)$

\begin{tabular}{cccc}
\hline Variabel & Mean & SD & $95 \%$ CI \\
\hline Usia Perawat & 31,83 & 4,362 & $30,63-33,03$ \\
\hline Masa Kerja & 5,89 & 3,286 & $4,98-6,79$ \\
\hline
\end{tabular}

Tabel 1 menunjukkan rerata umur perawat dalam penelitian ini adalah 31,83 tahun dengan standar deviasi 4,362. Tabel menunjukkan rerata umur perawat dalam populasi berada pada rentang 30,63-33,03. Masa kerja perawat dalam penelitian ini adalah 5,89 tahun dengan rerata masa kerja perawat dalam populasi berada pada rentang 4,98-6,79.

Tabel. 2

Distribusi Responden Perawat Berdasarkan

Karakteristik Jenis Kelamin dan Pendidikan $(n=53)$

\begin{tabular}{cccc}
\hline No & Variabel & Frekuensi & Presentase \\
\hline Jenis Kelamin & Perempuan & 53 & $100 \%$ \\
\hline \multirow{2}{*}{ Pendidikan } & DIII Keperawatan & 48 & $90,6 \%$ \\
\cline { 2 - 4 } & S1 Keperawatan + Ners & 5 & $9,4 \%$ \\
\hline
\end{tabular}

Tabel 2 menunjukkan bahwa menunjukkan bahwa keseluruhan perawat berjenis kelamin perempuan dan sebagian besar perawat berpendidikan DIII Keperawatan $(90,6 \%)$.

Tabel. 3

Distribusi Responden Perawat Berdasarkan Kepedulian Perawat Melakukan Tindakan Mengurangi Nyeri

$(n=53)$

\begin{tabular}{cccc}
\hline \multirow{2}{*}{ No } & $\begin{array}{c}\text { Variabel } \\
\text { Kepedulian Perawat }\end{array}$ & \multirow{2}{*}{ Frekuensi } & \multirow{2}{*}{ Presentase } \\
\hline \multirow{2}{*}{ Sebelum } & Belum Peduli & 46 & $86,8 \%$ \\
\cline { 2 - 4 } & Peduli & 7 & $13,2 \%$ \\
\hline \multirow{2}{*}{ Setelah } & Belum Peduli & 27 & $50,9 \%$ \\
\cline { 2 - 4 } & Peduli & 26 & $49,1 \%$ \\
\hline
\end{tabular}

Tabel 3 menunjukkan bahwa sebelum intervensi hanya $7(13,2 \%)$ orang perawat yang peduli melakukan upaya mengurangi nyeri pada saat prosedur penusukan tumit dan pembuluh darah vena. Setelah intervensi terjadi peningkatan peduli perawat sebanyak $26(49,1 \%)$ perawat yang melakukan upaya mengurangi nyeri pada saat prosedur penusukan tumit dan pembuluh darah vena. 
Tabel. 4

Presentase Tindakan yang Digunakan untuk Mengurangi Nyeri $(n=26)$

\begin{tabular}{clcc}
\hline No & \multicolumn{1}{c}{ Variabel } & Frekuensi & Presentase \\
\hline 1 & Fucilitated Tucking & 3 & $11,54 \%$ \\
\hline 2 & Pemberian Dot/Kempeng & 12 & $46,15 \%$ \\
\hline 3 & Pembedongan & 11 & $42,31 \%$ \\
\hline
\end{tabular}

Tabel 4 menunjukkan bahwa tindakan yang sering digunakan oleh perawat dalam upaya mengurangi nyeri yaitu pemberian dot/kempeng $(46,15 \%)$.

\section{Pengaruh Penerapan Media terhadap Kepedulian Perawat dalam Upaya Mengurangi Nyeri}

Tabel. 5

Sebaran dan Perbedaan Skor Kepedulian Perawat Sebelum dan Setelah Perlakuan Februari-April $2018(\mathrm{n}=53)$

\begin{tabular}{cccccc}
\hline \multirow{2}{*}{ Variabel } & \multicolumn{3}{c}{$\begin{array}{c}\text { Pengukuran } \\
\mathrm{n}(\%)\end{array}$} & \multirow{2}{*}{$95 \%$ CI } & \multirow{2}{*}{ p-Value } \\
\cline { 2 - 5 } $\begin{array}{c}\text { Kepedulian } \\
\text { Perawat }\end{array}$ & \multicolumn{3}{c}{ Belum Peduli } & Peduli & \\
\cline { 2 - 5 } & Sebelum & $46(86 \%)$ & $7(13,2 \%)$ & $0,04-0,23$ & \multirow{2}{*}{0,001} \\
\cline { 2 - 5 } & Setelah & $27(50,9 \%)$ & $26(49,1 \%)$ & $0,35-0,63$ & \\
\hline
\end{tabular}

Tabel 5 menunjukkan uji statistik diperoleh perubahan pada kepedulian perawat setelah perlakukan dengan $(\mathrm{p}$-value $<0,05)$.

\section{PEMBAHASAN}

\section{Karakteristik Responden \\ Usia}

Hasil penelitian ini memberikan gambaran bahwa usia perawat berkisar antara 2340 tahun dengan rerata usia 31,83 tahun. Usia sangat berkaitan dengan tingkat kedewasaan dan kemampuan individu dalam melakukan pekerjaannya. Semakin tinggi usia seseorang semakin meningkat kesempatan belajar dan pengalaman yang dimiliki. Berdasarkan hasil penelitian Husnayain et al., (2019) dalam penelitiannya mengenai faktor yang berhubungan dengan motivasi perawat bagian rawat inap, sebanyak 31 responden perawat dalam rentang usia produktif 30-39 tahun dari keseluruhan responden 64 orang. Kematangan usia seseorang akan mempengaruhi proses pengambilan keputusan dan proses berfikir dalam melakukan sesuatu sehingga dapat bekerja sama dengan teman kerja dalam melaksanakan tugas perawat.

Hal ini sejalan dengan hasil penelitian Ezdha (2018) tentang analisis hubungan antara kategori usia dengan persepsi perawat terhadap budaya keselamatan pasien di Rumah Sakit Setia Mitra Jakarta menggunakan uji chi square didapatkan nilai $\mathrm{p}=0.048$ $(\mathrm{p}<0,05)$. Hasil analisis ini menunjukkan ada hubungan yang bermakna antara usia dengan persepsi perawat terhadap budaya keselamatan pasien. Dari hasil analisis diperoleh pula nilai $\mathrm{OR}=0.25$, artinya perawat dengan usia 20-35 tahun mempunyai peluang 0.25 kali persepsi baik dibanding perawat dengan usia $>35$ tahun. Rentang usia tersebut merupakan periode seseorang paling produktif, memiliki kematangan secara fisik maupun secara psikologis serta memiliki kemampuan dalam mengaktualisasikan pengetahuan dan kompetensi yang dimiliki untuk mencapai tujuan didalam karirnya. 


\section{Masa Kerja}

Masa kerja perawat dalam penelitian ini didapatkan masa kerja tersingkat satu tahun dan terlama 12 tahun. Masa kerja sangat berpengaruh terhadap produktifitas kerja seseorang. Semakin lama seseorang bekerja, maka semakin banyak pengalaman kerja yang nantinya akan meningkatkan produktifitas dari orang tersebut. Hal ini sejalan dengan hasil penelitian yang dilakukan Sarastya et al., (2018) tentang hubungan beban kerja terhadap mekanisme koping perawat di ruang rawat inap didapatkan jumlah terbanyak lama bekerja berada pada $>3$ tahun dengan jumlah 29 responden $(60,4 \%)$. Seseorang yang telah bekerja di bidangnya masing-masing dalam waktu tertentu akan menunjukkan lamanya dia bekerja dalam bidang tersebut.

\section{Jenis Kelamin}

Hasil penelitian menunjukkan berdasarkan jenis kelamin keseluruhan perawat yang ada di Ruang Perinatologi RSCM berjenis kelamin perempuan (100\%). Hasil penelitian Anggoro et al., (2018) menunjukkan bahwa dari 55 responden laki-laki sebanyak $39(70,9 \%)$ berperilaku caring dengan baik dan dari 77 responden perempuan sebanyak $44(57,1 \%)$ berperilaku caring dengan baik. Hal ini menunjukkan mayoritas perawat laki-laki maupun perempuan memiliki perilaku caring dengan baik, jenis kelamin tidak membedakan perilaku caring perawat. Hasil penelitian ini menunjukkan p-value $(0,107>0,05)$ tidak ada hubungan antara jenis kelamin dengan perilaku caring perawat.

\section{Pendidikan}

Tingkat pendidikan merupakan hal yang sangat mempengaruhi seseorang dalam berperilaku dan bekerja. Semakin tinggi tingkat pendidikan seseorang semakin tinggi pemahaman dan kompetensi di bidang ilmunya. Hasil penelitian didapatkan perawat dengan tingkat pendidikan DIII keperawatan lebih banyak dibandingkan dengan yang berpendidikan sarjana sehingga bisa dikatakan bahwa perawat pelaksana yang ada di RSUP Cipto Mangunkusumo masih berpendidikan vokasional dan hanya sebagian kecil yang Ners.

Performa perawat dalam bekerja ternyata memiliki korelasi yang sangat kuat dengan Quality of Nursing Work Life (QNWL), faktor tingkat pendidikan seorang perawat memengaruhi performa kerja perawat di tempat dia bekerja dan performa kerja tersebut berhubungan erat dengan QNWL (Nursalam et al., 2018).

\section{Teknik Non Farmakologi}

Non nutritive sucking (NNS) adalah suatu cara untuk merangsang penghisapan mulut bayi menggunakan dot dari silikon (empeng) tanpa pemberi ASI atau susu formula (Pramesti et al., 2018). Berdasarkan hasil penelitian Pramesti et al., (2018) dari hasil uji independent t-test didapatkan nilai $\mathrm{p}$-value $0,000(\mathrm{p}<\alpha)$ sehingga dapat disimpulkan ada pengaruh pemberian non nutritive sucking (pacifier) terhadap respon nyeri neonatus saat dilakukan pemasangan infus. Menurut Peng et al., (2018) dari hasil penelitian tentang kombinasi non nutritive sucking + ASI peroral + facilitated tucking sangat efektif mengurangi nyeri pada bayi prematur yang dilakukan prosedur pengambilan darah di tumit.

Sejalan dengan hasil penelitian Sofiyah et al., (2020) tentang pengaruh pembedongan terhadap penurunan nyeri pada bayi yang dilakukan tindakan invasif pengambilan darah didapatkah hasil uji statistik dengan uji Mann Whitney yang telah 
dilakukan intervensi kepada 10 responden kelompok kontrol dan 10 responden kelompok intervensi didapatkan hasil 4,000 dengan p-value 0,000 $(\alpha=0,05)$ maka H0 ditolak dengan interpretasi terdapat pengaruh pembedongan terhadap penurunan tingkat nyeri pada bayi yang dilakukan tindakan invasif ambil darah.

\section{Penerapan Poster terhadap Kepedulian Perawat dalam Upaya Mengurangi Nyeri}

Hasil analisis menunjukkan terdapat perbedaan bermakna secara signifikan pada skor kepedulian perawat dalam upaya mengurangi nyeri pada neonatus sebelum dan setelah penerapan poster.

Menurut Ariani \& Aini (2018) caring adalah tindakan yang digunakan perawat untuk memberikan pelayanan kesehatan kepada pasiennya dan caring merupakan suatu sikap peduli, hormat dan menghargai orang lain. Caring akan terlihat dari perilaku perawat yang melakukan asuhan keperawatan dan dari perilaku caring akan berdampak bagi yang menerima perilaku caring tersebut, yaitu: salah satunya pasien.

Caring perawat dapat meningkatkan kesembuhan pasien karena pasien merasa terpenuhi kebutuhan fisik, emosi dan spiritual (Purwaningsih, 2018). Perilaku caring dinyatakan sebagai perasaan yang memberikan perubahan dalam perilaku, keselamatan dan pekerjaan sesuai dengan standar. Perawat dalam memberikan asuhan keperawatan dengan rasa kebaikan, perhatian, sentuhan kasih sayang, kehadiran dan selalu mendengarkan akan membuat pasien atau keluarga merasa sangat bahagia, percaya dan nyaman dengan perawat.

Sejalan dengan penelitian Rahayu \& Susilawati et al., (2018) tentang hubungan pengetahuan dengan perilaku caring perawat, didapatkan hasil bahwa dari 27 responden yang berpengetahuan tentang caring yang baik memiliki perilaku caring yang baik sebanyak 25 orang $(92,5 \%)$ dan sebanyak 2 orang $(7,4 \%)$ yang memiliki perilaku caring yang kurang. Hasil uji statistik Chi-Square nilai $\mathrm{p}$-value sebesar $0,000(\mathrm{p}<\alpha)$ yang berarti terdapat hubungan yang signifikan antara pengetahuan dengan perilaku caring perawat pelaksana dan hasil analisa data nilai Odd Ratio 62,5, dimana perawat dengan pengetahuan caring baik mempunyai peluang 62,5 kali lebih besar memiliki perilaku caring yang baik dibandingkan perawat dengan pengetahuan caring kurang baik perawat.

Pengetahuan merupakan hasil tahu seseorang yang didapatkan melalui belajar, pengalaman dan lain-lain. Pengetahuan perawat sangat mempengaruhi perilaku caring perawat karena perawat yang mempunyai pengetahuan tentang caring yang baik mempunyai landasan teori yang cukup untuk dirinya dalam mempraktikkan caring. Dengan demikian dapat disimpulkan bahwa semakin baik tingkat pengetahuan perawat terhadap caring, maka akan semakin baik juga perilaku caring perawat tersebut (Rahayu \& Susilawati, 2018).

Manfaat caring sangat besar tercermin dalam setiap interaksi antara perawat dan pasien karena bersikap caring terhadap pasien merupakan indikator utama dalam pelayanan keperawatan. Bentuk hubungan antara perawat dan pasien juga adalah hubungan yang harus dipertanggung jawabkan secara professional (Octaviani et al., 2020). Berdasarkan hasil penelitian yang dilakukan oleh Suprajitno et al., (2020) mengenai perilaku caring perawat saat melakukan tindakan pengkajian pasien sebanyak 92,5\% dan penelitian Firmansyah et al., (2019) juga didapatkan hasil perilaku carng perawat sebesar 52,1\%. Dalam memberikan asuhan keperawatan yang maksimal dan mencapai pelayanan yang berkualitas terhadap pasien, perawat harus memiliki sikap caring untuk memberikan kepuasan dalam hal pelayanan keperawatan yang diberikan 
sehingga pasien merasa dipedulikan oleh perawat dan sebagai bentuk perhatian yang diberikan perawat kepada pasien.

Salah satu upaya yang dapat dilakukan dalam meningkatkan perilaku caring perawat adalah penerapan media diantaranya poster manajemen non farmakologi. Poster merupakan sebuah rancangan kombinasi visual dengan warna untuk menarik perhatian. Poster merupakan sebuah media dalam penyampaian sebuah ide, pesan, informasi dan saran sehingga dengan adanya poster akan meningkatkan keinginan untuk melihatnya dan melaksanakan isi pesan tersebut. Rothewelle (2019) menjelaskan bahwa pemahaman dan penafsiran orang tentang suatu materi akan lebih baik jika teks dan gambar digabungkan dan pembaca mungkin tidak memahami teks, tetapi dapat dengan mudah memahami gerakan dan ekspresi wajah dalam gambar. Kelebihan dari poster itu adalah menimbulkan daya tarik tersendiri dikarenakan lebih banyak memuat gambar dibandingkan teks, mudah diingat dan mudah dibaca, bahasa yang digunakan cukup dimengerti dan memilki tujuan yang jelas serta harga pembuatannya cukup murah (Wicaksana et al., 2020).

Pemasangan poster yang dilakukan di ruang perawatan meningkatkan keinginan perawat untuk lebih peduli kepada diri sendiri dan pasien. Salah satu faktor pembentukan sikap seseorang adalah komunikasi sosial yang berupa informasi yang diterima oleh individu tersebut. Sejalan dengan hasil penelitian Hartati et al., (2020) yang menganalisis tentang efektivitas media poster terhadap tingkat pengetahuan dan sikap remaja tentang pencegahan HIV/AIDS menunjukkan bahwa pada tingkat pengetahuan diketahui nilai $\mathrm{p}(\mathrm{sig})(0,000)<0,05$ yang artinya terdapat pengaruh penggunaan media poster terhadap pengetahuan remaja. Rata-rata skor pengetahuan sebelum diberikan intervensi dengan media poster sebesar 8,66 dan setelah diberikan intervensi dengan media poster skor rata-rata pengetahuan meningkat menjadi 12,33. Hal ini menunjukkan media poster efektif dalam peningkatan pengetahuan remaja tentang HIV/AIDS.

Harrison et al., (2019) dalam penelitiannya mengatakan poster berisikan gambar keseluruhan dengan sedikit teks lebih mudah dipahami oleh seseorang dan dengan adanya poster mencuci tangan yang diterapkan dalam penelitian didapatkan hasil responden lebih patuh dan paham dalam melakukan cuci tangan. Poster dapat menjadi alat pendidikan untuk mendapatkan pengetahuan dan informasi.

Hasil penelitian menunjukkan bahwa terjadi peningkatan kepedulian perawat setelah diberikan intervensi penerapan media berupa poster. Hal ini sejalan dengan penelitian yang dilakukan oleh Anitha et al., (2018) tentang poster sebagai media pengingat kepatuhan mencuci tangan bahwa kepatuhan perawat dalam kebersihan tangan meningkat setelah intervensi penerapan poster sebagai media pengingat $(\mathrm{p}<0,001)$.

Peneliti berpendapat bahwa dengan menggunakan poster sebagai media pengingat akan memberikan pengaruh positif terhadap peningkatan kepedulian perawat dalam upaya mengurangi nyeri pada neonatus saat prosedur penusukan tumit dan pembuluh darah vena. Dengan adanya poster perawat akan terus terpapar dalam upaya melakukan manajemen non farmakologi karena setiap hari perawat akan melihat poster manajemen non farmakologi yang terpampang di setiap Ruang Perinatologi. 


\section{SIMPULAN}

Penerapan penggunaan media poster terbukti efektif dalam meningkatkan caring perawat dalam upaya mengurangi nyeri pada saat prosedur penusukan tumit dan pembuluh darah vena pada neonatus dan manajemen non farmakologi yang paling banyak digunakan oleh perawat di Ruang Perinatologi untuk mengurangi nyeri adalah pemberian dot/empeng.

\section{SARAN}

Diharapkan penerapan manajemen nyeri non farmakologi pada saat prosedur penusukan tumit dan pembuluh darah vena pada neonatus di Ruang Perinatologi menjadi pelaksanaan yang berkelanjutan, dapat menjadi prosedur tetap dan menjadi sumber informasi perawat dalam meningkatkan kompetensi untuk mengurangi nyeri pada neonatus saat tindakan invasif.

Bagi peneliti selanjutnya bisa dilakukan penelitian melalui video tindakan non farmakologi untuk mengurangi nyeri dan penyebaran informasi video non farmakologi dilakukan melalui handphone perawat ke perawat lainnya, sehingga penyebaran informasi dan pengetahuan lebih maksimal.

\section{DAFTAR PUSTAKA}

Anggoro, W. T., Aeni, Q., \& Istioningsih. (2018). Hubungan Karakteristik Perawat dengan Perilaku Caring. Jurnal Keperawatan, 6(2), 98-105. https://doi.org/10.26714/jkj.6.2.2018.98-105

Anitha, Handiyani, H., \& Sukihananto. (2018). Pengaruh Penggunaan Poster sebagai Media Pengingat terhadap Kepatuhan Kebersihan Tangan Perawat Pelaksana di RSPI Prof Dr Suliant Saroso. The Indonesian Journal of Infectious Disease, 2231. https://media.neliti.com/media/publications/261795-none-249138e6.pdf

Ariani, T. A., \& Aini, N. (2018). Perilaku Caring Perawat terhadap Kepuasan Pasien Rawat Inap pada Pelayanan Keperawatan. Jurnal Keperawatan, 9(1), 58-64. I http://ejornal.umm.ac.id/index.php/keperawatan/isse/view

Constanza, M., Ramos, M., Korki, L., Candido, D., Costa, T., Leite, A. N., Manzo, B. F., Duarte, E. D., Harrison, D., \& Bueno, M. (2021). Painful Procedures and Analgesia in Hospitalized Newborns : A Prospective Longitudinal Study. Journal of Neonatal Nursing, 25(1), 26-31. https://doi.org/10.1016/j.jnn.2018.08.003

Delfatmawati \& Mariyana, R. (2020). Penerapan Atraumatic Care terhadap Respon Fisiologis dan Respon Psikologis yang Mengalami Hospitalisasi. Jurnal Human Care, 5(1), 356-364. https://ojs.fdk.ac.id/index.php/humancare/article/download/721/pdf

Dur, S., Caglar, S., Yildiz, N. U., Dogan, P., \& Varal, I. G. (2020). The Effect of Yakson and Gentle Human Touch Methods on Pain and Physiological Parameters in Preterm Infants During Heel Lancing. Intensive and Critical Care Nursing. https://doi.org/10.1016/j.iccn.2020.102886

Ezdha, A. U. A. (2018). Konstribusi Karakteristik Perawat yang Mempengaruhi Budaya Keselamatan Pasien di Rumah Sakit Kelas C Jakarta Selatan. Jurnal Keperawatan Abdurrab, 2(1). https://doi.org/https://doi.org/10.36341/jka.v2i1.465

Firmansyah, C. S., Noprianty, R., \& Karana, I. (2019). Perilaku Caring Perawat Berdasarkan Teori Jean Watson di Ruang Rawat Inap. Jurnal Kesehatan Vokasional, 4(1), 33-48. https://doi.org/10.22146/jkesvo.40957

Harrison, B. L., Ogara, C., Gladstone, M., Carrol, E. D., Richards-Dusabe, Lara, A. M., 
Ditai, J., \& Weeks, A. D. (2019). We have to Clean Ourselves to Ensure that Our Children are Healthy and Beautiful: Findings from A Qualitative Assessment of A Hand Hygiene Poster in Rural Uganda. BMC Public Health, 19(1), 1-11. http://eresources.perpusnas.go.id:2166/10.1186/s12889-018-6343-3

Hartati, I., Sumarni, E., \& Fransiska, R. (2020). Efektivitas Media Leaflet dan Poster terhadap Tingkat Pengetahuan dan Sikap remaja tentang Pencegahan HIV/AIDS di MAN2 Langsa. Jurnal Pendidikan dan Kesehatan, 3(2), 168-177. http://stikescnd.ac.id/jurnal/index.php/smart/article/view/56

Hertel, V. L., Aparecida, L., Colósimo, M., \& Rogéria, P. (2019). Perceptions of Nursing Professionals front the Pain of Newborns in a Neonatal Intensive Therapy Unit. Acta Scientiarum, $1-7$. https://doi.org/10.4025/actascihealthsci.v41i1.40288

Husnayain, I., Andayanie, E., \& Septiyanti. (2019). Faktor yang Berhubungan dengan Motivasi Perawat Bagian Rawat Inap. Window of Health, 2(4), 382-388. https://jurnal.fkmumi.ac.id/index.php/woh/article/download/214/90/

Mohammed, A. R. A. (2018). Effect of Facilitated Tucking Versus Swaddling Positions on Orogastric Tube Insertion Pain among Preterm Neonates, 7(5), 75-86. https://doi.org/10.9790/1959-0705017586

Murtiningsih, \& Nurbayanti, S. (2021). The Effects of Breast Feeding and Massage on Neonatus Pain during Intravenous Blood Sampling Procedures. Journal of Neonatal Nursing, 1-6. https://doi.org/10.1016/j.jnn.2020.05.005

Nursalam, N., Fardiana, A., Asmoro, C. P., Fadhillah, H., \& Efendi, F. (2018). The Correlation between the Quality of Nursing Work Life and Job Performance. Indian Journal of Public Health Research and Development, 9(10), 351-356. https://doi.org/https://doi. org/10.5958/0976-5506.2018.01364.5

Octaviani, N., Jauhari, M. Z., Wulandari, R. Y., \& Surmiasih. (2020). Perilaku Caring Perawat terhadap Kepuasan Pasien. Wellness and Healthy Magazine, 2(2), 321324. https://wellness.journalpress.id/wellness/article/view/22045/pdf

Oktaviani, E., Rustina, Y., \& Efendi, D. (2018). Facilitated Tucking Effective to Pain Relief on the Preterm Infants in Perinatal Unit. Jurnal Keperawatan Indonesia, 21(1), 9-16. https://doi.org/10.7454/jki.v21i1.539

Peng, H. F., Yin, T., Yang, L., Wang, C., Chang, Y. C., Jeng, M. J., \& Liaw, J. J. (2018). Non-Nutritive Sucking, Oral Breast Milk, and Facilitated Tucking Relieve Preterm Infant Pain during Heel-Stick Procedures: A Prospective, Randomized Controlled Trial. International Journal of Nursing Studies, 77, 162-170. https://doi.org/10.1016/j.ijnurstu.2017.10.001

Pramesti, T. A., Padmasari, I. G. A. R., \& Wardhana, Z. F. (2018). Pemberian NonNutritive Sucking (Pacifer) terhadap Respon Nyeri Neonatus yang Dilakukan Pemasangan Infus. Journal of Borneo Holistic Health, 1(1), 113-126. http://180.250.193.171/index.php/borticalth/article/download/381/264

Purwaningsih, D. F. (2018). Perilaku Caring Perawat Pelaksana di Ruang Rawat Inap. Jurnal Ilmiah Kesehatan, 9(1), 61-67. https://ojs.unsiq.ac.id/index.php/jik/article/download/152/61

Rahayu, S., \& Susilawati. (2018). Hubungan Pengetahuan dan Sikap dengan Perilaku Caring Perawat di Rumah Sakit. Faletehan Health Journal, 5(2), 77-83. https://journal.lppm-stikesfa.ac.id

Ranjbar, A., Bernstein, C., Shariat, M., \& Ranjbar, H. (2020). Comparison of Facilitated Tucking and Oral Dextrose in Reducing the Pain of Heel Stick in Preterm Infants : 
A Randomized Clinical Trial, BMC Pediatrics, 20(162), 1-10. https://doi.org/10.1186/s12887-020-2020-7

Rothewelle, J. C. de. (2019). Comics and Medical Narrative: A Visual Semiotic Dissection of Graphic Medicine. Journal of Graphic Novels and Comics, 10(5-6), 562-588. https://doi.org/10.1080/21504857.2018.1530271

Sarastya, R., Jumaini, \& Bayhakki. (2018). Hubungan Beban Kerja terhadap Mekanisme Koping Perawat di Ruang Rawat Inap Rumah Sakit Jiwa. Jurnal Online Mahasiswa, 5(2), 328-335. https://jom.unri.ac.id/index.php/JOMPSIK/article/view/21114/20433

Sofiyah, Y., Rosliana, A., \& Lusiani, E. (2020). Pembedongan Berpengaruh terhadap Penurunan Tingkat Nyeri pada Bayi yang Dilakukan Tindakan Invasif Ambil Darah. JKA, 7(1), 9-16. https://doi.org/10.33867/jka.v7i1.159

Suprajitno, Sari, Y. K., \& Anggraeni, E. N. B. (2020). Relationship of Nurse Caring Behaviour with Patient Satisfaction at the Emergency Department of Catholic Hospital of Budi Rahayu Blitar. Jurnal Ners dan Kebidanan, 7(1), 001-005. https://doi.org/https://doi.org/10.26699/jnk.v7i1.art.p001- 005

Walker, S. M., Neurosciences, C., Great, U. C. L., Street, O., Health, C., \& Kingdom, U. (2019). Long-term Effects of Neonatal Pain. Seminars in Fetal and Neonatal Medicine, 24(4), 1-21. https://doi.org/10.1016/j.siny.2019.04.005

Wicaksana, J., Atmadja, P., \& Asmira, Y. (2020). Pengembangan Poster Kesehatan Reproduksi Berbasis Pendidikan Karakter Menggunakan Canva pada Usia Remaja Sekolah di SMA. Jurnal Penelitian dan Pengkajian Ilmu Pendidikan eSaintika, 4(2), 160-172. https://journal-center.litpam.com/index.php/eSaintika/index

Williams, M. D., \& Lascelles, B. D. X. (2020). Early Neonatal Pain-A Review of Clinical and Experimental Implications on Painful Conditions Later in Life. Front Pediatr, 8(30), 1-18. https://doi.org/10.3389/fped.2020.00030 